\title{
RECENT DEVELOPMENTS IN ELECTRIC SMELTING IN CONNECTION WITH IRON AND STEEL.
}

\author{
By F. W. HARBORD, Assoc.R.S.Mines, F.I.C., Cooper's Hill College. \\ (A Paper read before the Faraday Society on Monday, March 6, 1905, DR. F. \\ Mollwo Perkin, Treasurer, in the Chair.)
}

Last year, as is probably well known to most of the members of this Society, the Canadian Government appointed a Commission to investigate the different thermo-electric processes for the smelting of iron ores and the manufacture of steel at work in Europe. The author acted as metallurgist to that Commission, and was asked by your Council to give a paper embodying the principal results of the investigations. The paper he has the honour of submitting to the Society this evening is in the main a résumé of the report of the Commission, giving descriptions of the furnaces employed, particulars of the methods of working, and the conclusions arrived at.

The Commission visited five different works-two in Sweden, two in France, and one in Italy-and saw various types of furnaces in operation, and obtained a good deal of information respecting other processes which had not passed beyond the experimental stage.

Electric smelting furnaces may conveniently be divided into three main classes-(I) The induction furnaces; (2) The resistance furnace; and (3) The arc furnace-and all these three are now being employed in the metallurgy of iron and steel.

The first type of furnace is especially adapted for melting, as distinct from smelting-that is to say, for melting down mixtures of different metals to form certain definite alloys, rather than for the reduction of the metals from their ores, although under certain conditions it can be used for the latter purpose. The second type can be used either as a melting or smelting furnace by varying the construction, and the third type, although generally especially designed for the direct smelting of ores, can also be adapted to either purpose. In all cases, whatever the type of furnace employed, the object is to supply the heat necessary for the particular operation by means of electric energy, the latter not being used to assist directly in the chemical reactions, such as reduction or oxidation; in this way the electric energy replaces the coal, coke, or gas, used for heating, and it will readily be realised that in countries where fuel is cheap, as it is in England, the circumstances are comparatively few where it can be commercially employed.

For certain purposes, however, where it is important to obtain a finished 

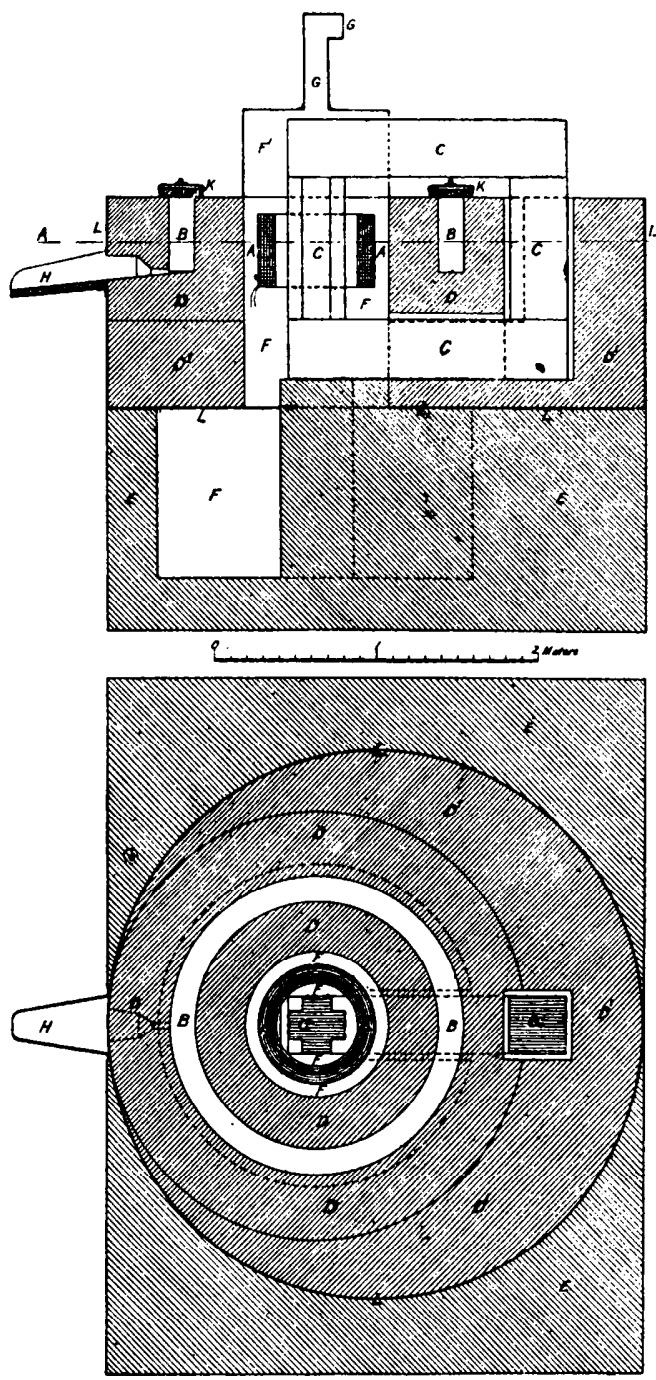

Section A $B$

Figs. I and 2.-Kjellin Furnace. Vertical Section through the tap hole and Sectional Plan on A B.-A A, Primary coil of insulated copper wire wound round laminated core, $C$, and to which delivered alternating current of 90 amperes at 3,000 volts ; B B, annular crucible or hearth, in which charge is melted and forms the secondary ; C C, laminated core ; $\mathrm{D}^{\prime} \mathrm{D}^{\prime}$, firebrick ; D D, Silica or Magnesite brick ; E E, ordinary brick foundation ; F F, air space for cooling primary ; F' and $\mathrm{G}$, iron cylinder with pipe attached to maintain a current of air flowing round primary; $\mathrm{H}$, spout from tap hole ; $\mathrm{KK}$, covers for annular crucible ; $L \mathbf{L}$, cylindrical iron casing of furnace. The covers of the crucible are on a level with the working floor, and the furnace is charged by removing these and throwing the scrap and iron into the crucible, $\mathrm{B}$. 


\section{SMELTING IN CONNECTION WITH IRON AND STEEL IqI}

product of great purity, where intense local heat and a non-oxidising atmosphere are required, electric energy enables us to meet the conditions more economically than can be done in any other way.

\section{Steel. Making.}

Under existing conditions, the electric furnace can compete with only two methods of steel manufacture. (I) The crucible steel furnace. (2) The open hearth, or Siemens, furnace for the production of highl-class carbon and special steels. The crucible steel process, as is well known, consists in selecting the purest materials, and mixing them in such proportion that, when melted in pots or crucibles, they will give a steel containing the required amount of carbon, and the highest qualities are made from selected cemented bars, which latter are made from the best Swedish Walloon iron. In this process practically all the impurities present in the original materials will be found in the finished steel.

The open hearth, or Siemens, process consists in melting pig iron and scrap steel in a gas-fired regenerative furnace, and in the gradual elimination of the impurities present by the oxidising action of oxides of iron, and the addition of suitable fluxes to retain these in the slag; during the operation the greater part of the carbon is removed, and the amount required in the finished steel is obtained by adding pig iron and alloys of manganese containing carbon to the bath of metal towards the end of the operation. The elimination of impurities in the bath of metal is never quite complete, and in addition the metal is liable to pick up certain impurities from the gas burnt in the furnace, and also to absorb or occlude certain proportions of different gases. The result is that although extremely high-class steel can be made in a Siemens furnace, it is not equal to the best crucible steel.

\section{THE INDUCTION FURNACE.}

This type of furnace is a large crucible in which the steel is melted by an induced current out of contact with any electrodes, completely protected from the action of any furnace gases, and practically protected from oxidation. It gives, from a metallurgical point of view, by far the nearest approach to the conditions of the crucible process, and provided the same care is taken in the selection of the raw materials, a finished product, equal in all respects to crucible steel, is obtained. The best known furnace of this type is the Kjellin furnace, which has been in operation at Gysinge, Sweden, since rgoo. Figs. I and 2, taken from the Canadian Commission Report, are a plan and sectional elevation of this furnace. This furnace is in effect a step-down transformer, in which the contents in the hearth or crucible form the secondary circuit of the transformer. The furnace is of $225 \mathrm{H}$.P. capacity, and to the primary $\mathrm{A} A$, Fig. $I$, is delivered an alternating current of 90 amperes and 3,000 volts, which induces a current in the secondary B B of 3,000 amperes and 7 volts. The primary A A consists of an insulated copper wire wound round one leg of the laminated core $\mathrm{CCCC}$, which forms the magnetic circuit. When an alternating current is passed through the coil, it excites a magnetic flux in the core, and the intensity of the current induced in the steel is then almost the same as the primary current multiplied by the turns of the wire in the primary coil. The tension of the current is naturally reduced in almost the same ratio as the intensity is increased. In this way it is possible to use an alternating-current generator of high tension, and to obtain a current of low voltage and great intensity in the furnace.

In starting the furnace, a little molten pig iron is poured into the circular 
trough $\mathrm{B}$ to form the secondary circuit, and at the finish of each heat, sufficient molten steel is left in the furnace to maintain this circuit. The circular hearth or crucible has movable covers on the top, of a size which can be easily raised by means of a bar, and the materials are charged in at the top by removing these covers. The charge at Gysinge usually consists of best Swedish pig iron, Walloon iron, and steel scrap, and the proportions of pig iron and steel scrap are varied according to the grade of steel it is desired to produce. Any grade of steel can be produced in this furnace from oro to $\mathrm{r}{ }^{5} \mathrm{o}$ per cent. or more of carbon, the only thing necessary being, to have ample power to insure rapid melting, and to obtain a sufficiently high temperature to enable the steel to be cast into ingot moulds.

During the melting there is practically no elimination of impurities, with the exception of a slight oxidation of the carbon, and to obtain a high-class product high-class materials must be used. The charge carefully calculated to give the required content of carbon is charged gradually during the operation as the materials melt down, the pieces of pig and scrap being of any convenient size. When the charge is completely melted, additions of ferro-manganese, ferro-silicon, or other materials which it may be desirable to alloy, are made, and when these are completely melted the charge is held in the furnace for a short time to raise the temperature to a good "tapping heat," when it is tapped in the usual way into a ladle placed under the spout $\mathrm{H}$.

The amount of energy consumed will vary with the grade of steel desired, a high carbon steel requiring less than a low carbon steel, as the former has a lower melting-point, and does not require to be raised to such a high final temperature to enable it to be cast into ingot moulds without "skulling," i.e., partially setting in the ladle. The average time for producing about one ton of steel ingots is six hours for high carbon steel and from seven to eight hours for dead soft, or nearly carbonless steel.

At Gysinge the current for operating the furnace is obtained from a single-phase revolving field alternator, which is rated at 3,000 volts and 90 amperes. It has 24 poles, and a nominal speed of 15 cycles per second. It is arranged with a vertical shaft, and is directly connected with a water wheel. The amount of energy consumed per ton of steel was very carefully determined by Mr. Brown, the electrician accompanying the Canadian Commission, by following various charges through, and taking readings regularly at short intervals during the working of the charge. The following, taken from Mr. Brown's report, gives particulars of the instruments used, and the final results obtained in two charges :-

"The voltage was measured with a Weston portable alternating-current voltmeter, having a scale reading up to $15^{\circ}$, and connected in series with multiplying resistance giving a ratio of $25: \mathrm{r}$.

"The current was read on two Hartmann and Braun ammeters, connected in parallel, and having scale readings 50 and 60 amperes respectively. These ammeters were calibrated by comparison with a Siemens and Halske standard ammeter, and the readings corrected accordingly. Calibration curves are given in the report of the Commission.

"The power was measured by means of a Weston portable indicating wattmeter having a scale reading up to 150 . The current coil used was arranged for 120 amperes, and multiplying resistances were connected in series with the voltage coil to make it suitable for 3,000 volts. This gives a ratio of $24: \mathrm{I}$ to obtain the results in kilowatts. The standard instruments were obtained from David Bergman, consulting engineer of Stockholm." 
Results of Charge 546.

High Carbon Tool Steel Carbon, $x \cdot 082$ per cent.

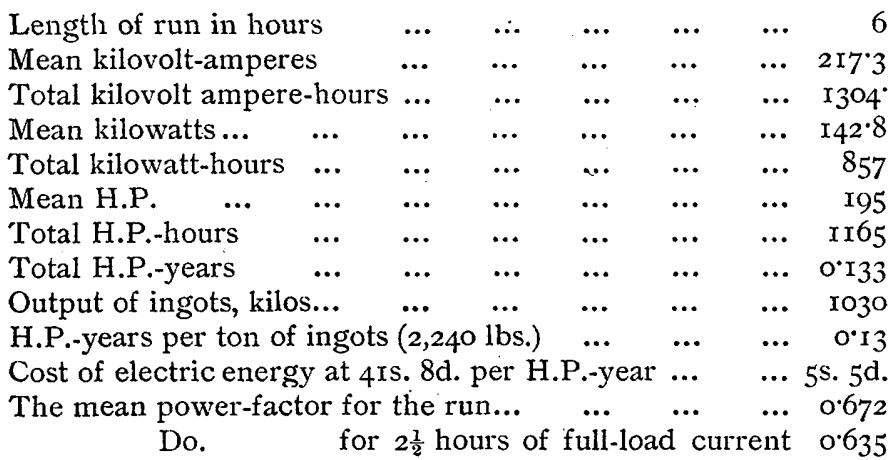

Results of Charge 547 .

Medium Carbon Steel Carbon $0^{\circ} \mathrm{J}^{\mathrm{J}} 7$ per cent.

$\begin{array}{llllllll}\text { Length of run in hours } & \ldots & \ldots & \ldots & \ldots & \ldots & 6 \frac{2}{3}\end{array}$

$\begin{array}{lllllll}\text { Mean kilovolt ampere } \ldots & \ldots & \ldots & \ldots & \ldots & \ldots & 232\end{array}$

$\begin{array}{llllll}\text { Total kilovolt ampere-hours } \ldots & \ldots & \ldots & \ldots & \ldots & \text { I546 }\end{array}$

$\begin{array}{llllllll}\text { Mean kilowatts ... } & \ldots & \ldots & \ldots & \ldots & \ldots & \ldots & \text { I } 49\end{array}$

$\begin{array}{llllllll}\text { Total kilowatt-hours } & \ldots & \ldots & \ldots & \ldots & \ldots & \ldots & 994\end{array}$

$\begin{array}{lllllllll}\text { Mean H.P. } & \ldots & \ldots & \ldots & \ldots & \ldots & \ldots & \ldots & 203\end{array}$

$\begin{array}{llllllll}\text { Total H.P.-hours } & \ldots & \ldots & \ldots & \ldots & \ldots & \ldots & \text { I350 }\end{array}$

$\begin{array}{llllllll}\text { Total H.P.-years } & \ldots & \ldots & \ldots & \ldots & \ldots & \ldots & \text { O. } 154\end{array}$

$\begin{array}{llllll}\text { Output of ingots obtained, kilos } & \ldots & \ldots & \ldots & \ldots & 955\end{array}$

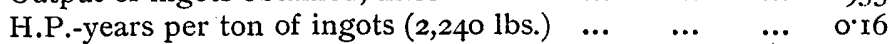

Cost of electric energy per ton of ingots at 4 Is. $8 \mathrm{~d}$. per

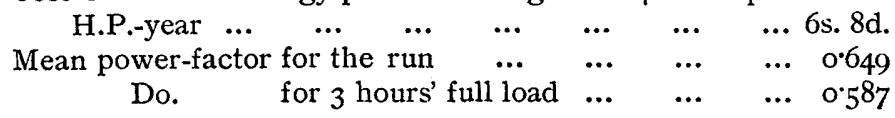

It will be noticed that the energy required for the 470 carbon steel was somewhat greater than for the $\mathrm{r}^{\circ} \circ \mathrm{o}$ per cent. carbon, which is what would be anticipated, and was confirmed by the other charges when making lower carbon steel.

Although this furnace is more particularly adapted for "crucible" metal melting, it can be, and has been, used for smelting the ore direct, and since my visit to Gysinge further experiments in this direction have been attended with considerable success.

Mr. Kjellin has sent me particulars of recent developments in a letter dated January 7 , 1905, which is as follows :-

"Having at last got a new turbine, we are able to increase the power at the furnace to 175 kilowatts (239 electric H.P.) instead of the maximum being $\mathrm{x} 65$, and this increase of power, together with a diminished area of contact between steel, masonry, and slag, has increased the output of the furnace from 4 tons to from $5^{\circ} 2$ to $5^{\circ} 5$ tons in 24 hours, which naturally makes the melting costs lower. Another reason for these good results is that, owing to some slight alterations, I have got the power applied more uniformly over the whole time of the charge. In future I shall be able to build the furnaces so that they shall consume the maximum power of the turbine or engine all the time. I have already done so in the case of a small trial-furnace, put up 
last summer in the south of France. The capacity of the Gysinge furnace with 175 kilowatts is now 1,450 kilogrammes, of which 900 kilogrammes are tapped each time. I have recently used pig and ore instead of pig and scrap, and this seems to answer very well. The ore used is briquettes from Herrang concentrates, containing about 70 per cent. of iron, and consequently practically no gangue, so that the wear and tear is not increased to such an extent as would be the case if the ore contained much gangue. The briquettes being very low in phosphorus, I can in this way get a high quality steel cheaper than by using scrap and pig, though the production of the furnace is only 60 to $6 \overrightarrow{5}$ per cent. of the production from cold scrap and pig. If using molten pig and ore I should get the same output from a given power as from cold pig and scrap, but the waste would be much lower, as the iron of the ore would be almost perfectly reduced."

It will be seen from above that pig and ore can be used in the furnace, but to obtain a high-class product none but extremely pure materials can be employed, and at present Swedish materials are probably the only suitable ones which are available. This furnace in its present form can only be used for the manufacture of tools and other high-class steels, and in the majority of cases, at all events outside Sweden, it will probably pay better to use pig and scrap only, as the saving effected by ore and pig when the reduced output is considered, cannot be very great.

\section{THE RESISTANCE FURNACE.}

In this type of furnace the heat is generated by the resistance offered by the whole, or a portion, of the furnace charge to a very powerful electric current. It is best represented by the Héroult and Keller furnaces, which are both employed commercially in the manufacture of steel and alloys of iron.

\section{The HÉRoult Process.}

The Héroult furnace for the manufacture of steel has been in successful operation now for several years. One 4-ton furnace at Kortfors, in Sweden, and a somewhat smaller furnace at La Praz, in the south of France, are producing steel commercially on a considerable scale, and of the highest quality. The furnace shown in Figs. 3 and 4, taken from the Canadian Commission Report, is a tilting furnace, so far as the construction of the body of the furnace is concerned, very similar to that of the well-known Wellman and Campbell tilting furnace. The furnace hearth is basic lined, as in the ordinary basic open hearth process, and two large electrodes pass vertically through the roof, and can be raised or lowered either by hand or automatically by a specially constructed regulator. An alternating current of 4,000 amperes and Iro volts is used at La Praz, and the intensity of the current passing through the bath is regulated by increasing or decreasing the width of the air-gatp between the clectrodes and the slag line. The section of the roof between the electrodes is usually made of bronze in order that no magnetic circuit may surround them. The electrodes may or may not be water-jacketed where they pass through the roof, but water-cooling not only increases the life of the furnace and electrodes, but enables a considerably larger output to be obtained. At the date of my visit the Kortfors furnace had water-jacketed electrodes, while the La Praz furnace had not, but the latter has since been provided with these.

One very great advantage connected with this furnace is that common steel scrap of good average quality, such as bar ends, rail ends, \&c., can be converted into steel of the highest quality, and it is not necessary to use an exceptionally pure or high-priced material, as in the induction furnace. The 


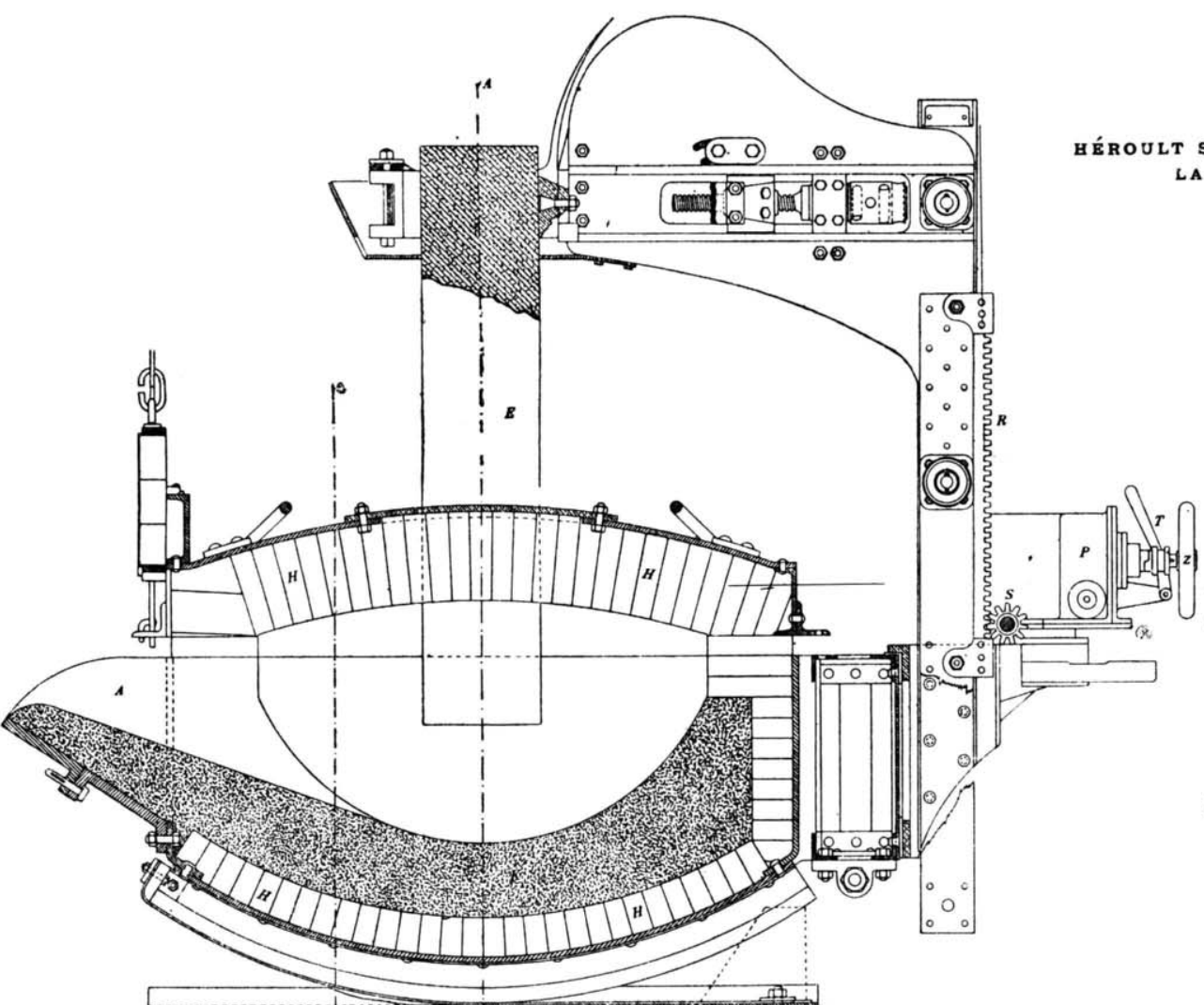

LA PRAZ YRANCE
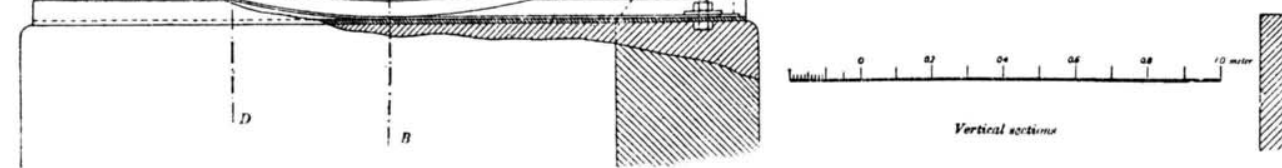

FIg. 3.-Vertical Section through the Pouring Spout of the Heroult Furnace at La Praz.-A Pouring spout ; $\mathrm{E}$, suspended electrode, of which there are two, passing through roof

$\mathrm{H}$, basic or burnt Dolomite bricks ; $\mathrm{H}^{2}$, Silica bricks of roof; $\mathbf{K}$, rammed basic material

$\mathrm{P}$, motor for driving automatic regulator, $\mathrm{T}$, lever for throwing motor, $\mathrm{P}$, out of action

$Z$, hand-wheel operating pinion, $\mathrm{S}$, for regulating electrodes by hand, $\mathrm{R}$, rack gearingiwith $\mathrm{S}$, by which electrode is raised or lowered. An alternating current of 4,000 amperes and

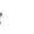
IIo volts is used. 
construction of the furnace is such that it enables the impurities in the scrap iron to be readily removed by the addition of suitable fluxes, and the slag an be poured off, and a new slag made at will to further remove any remaining impurities.

The furnace is charged by throwing the scrap iron or steel on to the hearth of the furnace through the doors at the end, and the electrodes are then lowered sufficiently to establish the electric current, the current passing through the charge from one electrode to the othcr. In the early stages of the heat, when the charge is melting down, the electrodes are generally in contact with some parts of it, and the energy is largely absorbed by the numerous high-resistance contacts and small arcs between the pieces forming the charge. During this period there are great variations in the resistance of the hearth, and violent fluctuations of the current, due to the continual change in contacts and disruption of the circuits owing to the melting of the different pieces. Gradually, however, the entire charge melts, an arc is established between each electrode, and the molten iron and the two arcs absorb the greater part of the energy. The position of each electrode is controlled by an automatic regulator by means of a small motor at the back of the furnace geared to the mechanism supporting the electrode. An electric mechanism actuated by variations of the voltage below or above certain predetermined limits controls the motor, which, according to the direction of its rotation, raises or lowers the electrode. During the melting stage, or when pouring off the slag, the arc is liable to be short-circuited, and it is better then to switch out the regulator and regulate by hand.

The method of working is as follows. Miscellaneous scrap, with some lime, is charged on the furnace hearth, and as the charge melts, further additions of scrap and lime are made, a little pure iron ore being added when the metal is entirely melted. After the bath has been molten for some time the furnace is tilted, the slag poured off, and finally raked off the surface, until practically nothing but metal remains in the furnace. A new slag is now formed by suitable additions of ore and lime; this is melted and kept in the furnace for some time, when it is removed in the same way as the first slag, and a third slag formed to remove the last traces of impurity. Ferromanganese in the case of low carbon steels is now added, and the metal is ready for pouring into the ladle, and teeming into the ingot mould. When high carbon steel is required at the end of the operation, "carburite," a mixture of pure iron and carbon, is added in the furnace in such a quantity as to give the percentage of carbon required in the finished steel. During my visit at La Praz, steel varying from 079 to 1000 per cent. was made without the slightest difficulty, the former being a special low carbon steel used for transformers.

The following, taken from the Canadian Report, gives some particulars of the electrical plants at La Praz, with electrical measurements taken (the charges given are for a low carbon and a high carbon steel). The usual charge was about three tons, but the low carbon heat was a very small one, as only a small quantity of this steel was required for a special order.

An alternating current is used, and is generated directly on the alternator at 1 lo volts. The alternator has $x 6$ poles, and operates at 250 revolutions per minute, giving a periodicity of 33 cycles. It is a revolving field machine, with horizontal shaft, and is directly connected to its water-wheel.

The water-wheel is operated with partial gate opening at the beginning of the charge to limit the output of the alternator during the period when the current Huctuates violently, but when conditions become more stable it is given full gate opening, and the alternator operates at full load through the

VOL. I-T6 
remainder of the run. When the furnace is tilted to rake off the slag the current is taken off, and again applied as soon as this operation is completed.

The electrical readings were taken on the regular switchboard volt-meter and kilowatt-meter, for which no calibration could be obtained. There was no ammeter in circuit, hence no determination of the current input or of the power-factor could be made.

The following readings were taken :-

Charge No. 658, March 5th. To obtain dead soft steel, Carbon 0.079:--

\begin{tabular}{c|c|c}
\hline Time. & Volts. & Kilowatts. \\
\hline P.M. & & \\
7.45 & IIO & 200 \\
7.50 & II5 & 220 \\
9.00 & - & 350 \\
9.30 & IIO & 330 \\
I0.00 & I08 & 360 \\
I0.30 & IO7 & 360 \\
I1.00 & 108 & 360 \\
II.30 & IO5 & 350 \\
I2.00 & I05 & 360 \\
& & \\
\hline
\end{tabular}

$\begin{array}{llll}\text { Beginning of run, partial gate opening, p.m. } & \ldots & \ldots & 7.45\end{array}$

$\begin{array}{lllllll}\text { Full gate opening, p.m. } & \ldots & \ldots & \ldots & \ldots & \ldots & 9.0\end{array}$

$\begin{array}{llllllll}\text { End of run, a.m. } & \ldots & \ldots & \ldots & \ldots & \ldots & \ldots & \text { 12.15 }\end{array}$

$\begin{array}{lllllll}\text { Length of run, total hours } & \ldots & \ldots & \ldots & \ldots & \ldots & 4 \frac{1}{2}\end{array}$

$\begin{array}{lllllllll}\text { Mean voltage } & \ldots & \ldots & \ldots & \ldots & \ldots & \ldots & \ldots & \text { 108 }\end{array}$

Mean kilowattts, partial gate opening $\quad \ldots \quad \ldots \quad \ldots \quad$ 2ro

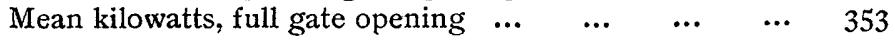

$\begin{array}{llllllll}\text { Total kilowatt-hours } & \ldots & \ldots & \ldots & \ldots & \ldots & \ldots & \text { r,410 }\end{array}$

Mean H.P., full gate opening $\quad \ldots \quad$.. $\quad \ldots \quad$.. $\quad \ldots \quad 480$

$\begin{array}{llllllll}\text { Total H.P.-hours } & \ldots & \ldots & \ldots & \ldots & \ldots & \ldots & \text { 1,920 }\end{array}$

$\begin{array}{llllllll}\text { Total H.P.-years } & \ldots & \ldots & \ldots & \ldots & \ldots & \ldots & 0.219\end{array}$

$\begin{array}{lllllll}\text { Output of ingots, } \text { kgs.... } & \ldots & \ldots & \ldots & \ldots & \ldots & \mathbf{1 , 2 8 3}\end{array}$

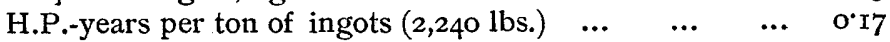

Cost of electric energy per ton of ingot, at $4 \mathrm{xs} .8 \mathrm{~d}$. per

$$
\begin{array}{lllllllll}
\text { H.P.-year } & \ldots & \ldots & \ldots & \ldots & \ldots & \ldots & \ldots & 7 \text { s. Id. }
\end{array}
$$

Charge No. 66o, March 6th. For tool steel, Carbon I'or6 :-

\begin{tabular}{c|c|c}
\hline Time. & Volts. & Kilowatts. \\
\hline A.M. & & \\
II.45 & I20 & 220 \\
I2.0 & I20 & 200 \\
P.M. & & \\
I2.15 & II5 & 225 \\
2.45 & IIO & 340 \\
3.45 & I08 & 350 \\
4.15 & 107 & 340 \\
4.45 & 107 & 340 \\
5.15 & I05 & 340 \\
5.45 & I0 & 340 \\
6.15 & I I0 & 330 \\
6.45 & I 10 & 340 \\
& & \\
\hline
\end{tabular}


Beginning of run, partial gate opening, a.m. $\quad \ldots \quad$... II.4O

$\begin{array}{lllllll}\text { Full gate opening, p.m. } & \ldots & \ldots & \ldots & \ldots & \ldots & \pm 2.45\end{array}$

$\begin{array}{llllllll}\text { End of run, p.m. } & \ldots & \ldots & \ldots & \ldots & \ldots & \ldots & 7.40\end{array}$

$\begin{array}{lllllll}\text { Length of run, total hours } & \ldots & \ldots & \ldots & \ldots & \ldots & 8\end{array}$

$\begin{array}{lllllllll}\text { Mean voltage } & \ldots & \ldots & \ldots & \ldots & \ldots & \ldots & \ldots & \text { iro }\end{array}$

$\begin{array}{lllll}\text { Mean kilowatts, partial gate opening } & \ldots & \ldots & \ldots & 215\end{array}$

$\begin{array}{llllll}\text { Mean kilowatts, full gate opening } & \ldots & \ldots & \ldots & \ldots & 340\end{array}$

$\begin{array}{llllllll}\text { Total kilowatt-hours } & \ldots & \ldots & \ldots & \ldots & \ldots & \ldots & 2,580\end{array}$

$\begin{array}{llllll}\text { Mean H.P., full gate opening... } & \ldots & \ldots & \ldots & \ldots & 462\end{array}$

$\begin{array}{llllllll}\text { Total H.P.-hours } & \ldots & \ldots & \ldots & \ldots & \ldots & \ldots & 3,500\end{array}$

$\begin{array}{llllllll}\text { Total H.P.-years } & \ldots & \ldots & \ldots & \ldots & \ldots & \ldots & 0_{4}\end{array}$

$\begin{array}{lllllll}\text { Output of ingots, } k g s . . . & \ldots & \ldots & \ldots & \ldots & \ldots & 2,34 \mathbf{I}\end{array}$

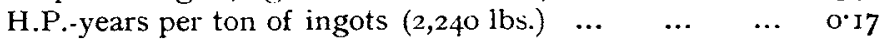

Cost of electric energy per ton of ingot, at 4 Is. $8 \mathrm{~d}$. per

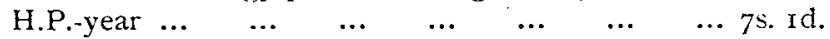

In the above figures of energy consumed the short periods have been neglected during which the current was taken off to remove the slag. The violent fluctuations of the current and the liability to short circuit make it desirable to limit the possible current to a moderate overload by the use of a suitably designed alternator and transformer.

It will be noted that the energy consumed per ton of ingot produced was the same in the low carbon steel as in the high carbon steel, but this is due largely to the smallness of the charge in the former case, and had it been a full heat, the energy consumed would have been considerably less. In the case of charge No. 660 the bath was completely melted and decarburised and sufficiently hot to tap, five hours after starting, and had ordinary structural steel been required it would have been tapped then : the remaining three hours were spent in purifying the metal by slagging and melting the carburising additions. The energy consumed up to five o'clock was only - I I E.H.P.-years per ton of ingots, instead of ' I 70 for the high-grade carbon steel.

\section{The Keller Steel Process.}

At Livet, at the works of Messrs. Keller, Leleux, \& Co., the process of steel-making is not carried on commercially, the chief business of this frrm being the manufacture of alloys. They have, however, an experimental furnace of about $35 \mathrm{cwt}$. capacity, in which they made an experimental heat. The furnace employed was identical, from a metallurgical and an electrical point of view, with the Héroult furnace, differing only in details as to tilting, \&c. The electrodes passed through the roof, an alternating current was employed ; common scrap was the raw material, and purification was effected by removing and renewing the slag several times. The charge made was of medium carbon, and the energy consumed was about ' 120 E.H.P.-years per ton of ingots made. Before considering arc furnaces it may be desirable to compare the three processes of steel-making above described.

Comparison of Kjellix, Héroult axd Keller Processes of SteielMakixg.

The amount of electric energy consumed by the Kjellin or Héroult process, as determined experimentally and confirmed by figures supplied from the books of the two firms, was practically the same when all grades of steel are considered, and wages for furnaces of the same 
output would be about the same. The cost of repairs, refractories, \&c., it is very difficult to estimate, but from figures taken from the respective works' books these are more costly in the Héroult than in the Kjellin, the respective figures being $5 \mathrm{~s}$. Iod. and $2 \mathrm{~s}$. 6d. per ton respectively. In addition to this we have to add, in the case of the Héroult process, the cost of electrodes, about tenpence per ton. Assuming that the cost of scrap pig, \&c., in both cases was the same, the difference in the cost of production would not be more than a few shillings per ton one way or the other: unless one could compare two furnaces working under identical conditions over a considerable period of time it would be unfair to draw conclusions. Since my visit to La Praz, Mons. Héroult has written to say that he has increased his output from 4 to 7 tons in the twenty-four hours; and Mr. Kjellin has increased his from 4 to 5 tons, which makes it still more difficult to compare the cost of production. The chief point, however, when one process has an advantage over the other is in the cost of raw material. The Kjellin process, to produce the highest class tool steel, is limited to the best Swedish scrap and the best Swedish pig, or pig and ore, whereas common miscellaneous scrap is the raw material used in the Héroult process. In Sweden this high-class scrap can be obtained at a comparatively low figure, but in other countries Walloon scrap, if obtainable at all, which is not likely, would cost probably $£ 12$ per ton, and possibly more, and it would most likely be necessary to buy the Walloon bars at the same price as bars for cementation. On the other hand ordinary steel scrap in England can be bought from 50s. to 60s. per ton, so that in countries outside Sweden the Héroult process has a great advantage. It is quite possible that Mr. Kjellin may be able to modify his furnace so that he can renew his slag and thus effect purification in the same way as in the Héroult process, but in its present form it is limited to the purest material either as scrap or scrap pig ore. His latest results with pure ore have no doubt reduced the costs, but the Héroult process still has a great advantage as regards the raw materials.

\section{Quality.}

So far as analytical, mechanical, microscopic, and workshop tests show, steels can be made either by the Kjellin, Héroult, or Keller process equal in every respect to best crucible steel. A large number of analyses taken from the centre, top, bottom, and outside of different ingots showed the steel to be remarkably uniform and free from all liquation of the impurities. The steels were also tested for maximum stress, elastic limit, elongation, \&c. The most important tests from the tool steel point of view, however, were those made at Woolwich under the supervision of Mr. H. F. Donaldson, Chief Superintendent of the Ordnance Factories.

A number of different steels varying in carbon from 0.8 to 1.30 per cent. were sent to Woolwich and forged into turning tools, comparative trials being made against turning tools of high-class Sheffield steel known as Grade "A" containing I ${ }^{3} 8$ per cent. of carbon, and also against Mushet steels. Steels lower in carbon than the standard steel were purposely sent, to determine, as far as possible, the point in carbon content, when the steels ceased to be equal to the Sheffield steels. Mr. Donaldson reported that the material was not as good as Mushet's steel, and at a cutting speed of 19 feet per minute was useless, whereas the Mushet steel was working well within its capacity. As compared with Grade "A," the results showed that, speaking generally, there was little difference between this and most of the steels experimented with. One peculiarity noticed in using the electric furnace steels as against Mushet's 
steel was an exceptional tendency to build up a false edge from the material operated upon. A reference to the tables on pages 86,87 , and 88 in the Canadian Report will show that this tendency became more noticeable as the carbon decreased. Although the steels examined gave practically the same results as Grade "A," when the actual detailed results are examined as to length of run and material removed in a given time, they divide themselves into two classes, those quite equal, and those not quite equal to Grade "A." With one exception in every trial with steel above $r^{\prime 20}$, the results were equal to those obtained with Grade "A," those marked as not equal being lower carbon steel. This was to be anticipated; but the fact that in Mr. Donaldson's opinion the general behaviour of the steels was equal to Grade "A," shows that even in the lower carbon steels the material was exceptionally good. It is important to remember that these steels cannot be compared with the special high-speed tool steels which are so largely replacing carbon steels for turning tools, and the comparison with Mushet's steel was only made to see if the steels under experiment were in any way superior to the ordinary carbon steels.

The quality of the steel, whether made in the induction furnace of Kjellin or a furnace of the resistance type, like the Héroult or the Keller, seems to be equal in all respects, and the selection of one type of furnace or another would depend almost entirely upon local conditions. In each case steel equal to high-class crucible can be made, although the Kjellin process undoubtedly approaches most nearly to the conditions of crucible steel manufacture; the absence, however, of any very appreciable amount of oxygen in the Héroult furnace is shown by calcium carbide having been found in the slag, according to some recent analyses of Mons. Héroult. The cost of production in either process will thus vary with the raw material available, but under the same conditions as to the cost of materials, and taking fuel at the present price in this country, and electric energy at $£$ ro per E.H.P. year, which is a price at which, under favourable conditions, it might be generated, either process could produce steel at a price lower than the cost of crucible steel : in other words, the electric furnace, even under English conditions, is a cheaper melter than the crucible furnace.

In the present stage of development, neither type of furnace can be regarded as a competitor to either the Siemens or the Bessemer processes for the production of rail and structural steel, and they can only compete successfully in the production of high-class crucible steel or steels for ordnance and other special purposes made in the Siemens furnace. In cases where very large steel castings are required of crucible steel quality, several clectric furnaces, working so that they could be tapped into a common receptacle, before pouring the steel into the mould, should give excellent results and be much more economical than the crucible process. Under favourable conditions, electric energy might compete with gas as regards cost, but until it is possible to use furnaces of from $3^{\circ}$ to 40 tons capacity, the extra labour charges inseparable from small furnaces will prevent them from holding their own against the Siemens or Bessemer process.

So far as the steel worlis engineer is concerned, there is no difficulty in designing a furnace of any size required, as furnaces, very similar in general design to the Héroult furnace, holding 200 tons of molten steel, are at present working both in England and America, and it only remains for the electrical engineer to arrange for the electrical heating without unduly weakening the roof or other parts of the furnace. Provided this can be done, under favourable conditions, where electric energy is so cheap that it can compete with producer gas as a heat producer, there is not the least reason 
why the present 5 ton electric furnace should not develop into a 40 or 50 ton furnace, in the same way that the 5 ton ordinary Siemens furnace has developed during the last twenty-five years.

\section{The Resistaxce Furnace for Direct Smelting from the Ore.}

With the exception of an experiment made at La Praz, by Mons. Héroult in one of his small furnaces, no direct smelting was investigated by the Canadian Commission until they visited the works of Messrs. Keller, Leleux, $\&$ Co. The experiments witnessed there were, from the Canadian standpoint, by far the most important, as they demonstrated the possibility of making pig, varying in composition to suit the requirements either of the acid or basic Bessemer, the acid or basic Siemens, or the foundry. From a commercial point of view, the manufacture of pig iron in the electric furnace is of little interest to the English electrician or metallurgist, as with our cheap supply of fuel no electric furnace can compete with a modern blast furnace. In Canada the conditions are different, as in some districts they have immense deposits of iron ore available, as well as water power, while no fuel suitable for blast furnace purposes can be obtained except at prohibitive prices. I am informed that electric energy is actually being distributed in some parts of Canada for less than $\$$ Io per E.H.P. year, so that the possibility of developing their iron ore resources by the electric furnace is a matter of great importance to the colony.

In various other countries, especially the South American Republic, such as Brazil and the Argentine Republic, and various other parts of the world where blast furnaces are impossible at present, the electric furnace might do excellent work. The type of electric furnace used for the reduction of iron ore is practically identical with that used for the production of the various iron alloys which cannot be made in a blast furnace. Amongst these may be mentioned rich ferro-chrome of 60 per cent. chromium and above, ferrotungsten, and rich ferro-silicon from 25 per cent. to 80 per cent., all of which are being largely used in the manufacture of various special steels for armour, projectiles, \&c., and it is in this direction that the electric furnace is likely to develop in England, so far as direct smelting is concerned.

The furnace used in the experiments at Livet is shown in Figs. 5 and 6. It consisted of two vat-shaped furnaces connected at their lower ends by a central well. Preferably four furnaces are grouped together, so that the metal as it is reduced collects in the central well. If four hearths are used, they can be divided into groups which are connected with each other in series, the two hearths forming each group being connected with each other in parallel. In such an arrangement the electric current will be broken during casting when the well is emptied of its contents, and this will not only interfere with the working of the furnace, but also with the working of the electric generators. To avoid this, a carbon block is built into the sole of each furnace, and these are connected by bars of copper, so arranged that they connect hearths of opposite polarity. As the flow of the current through the fused material decreases during casting, it flows through the sole of the hearths and copper conductors, and increases in direct ratio with the fall of the current in the fused mass connecting the hearths: and finally, when the hearth is emptied, the entire current flows through the outside conductors.

After casting, the fused metal again collects in the central well or crucible, and remakes the broken circuit, so that the current again begins to flow through the fused mass. These shunt connections prevent any irregularity or great variation in the distribution of the current, but for this arrange- 
The Kaller Eleotrlo High Purnado with a

plurenles of Hearithe
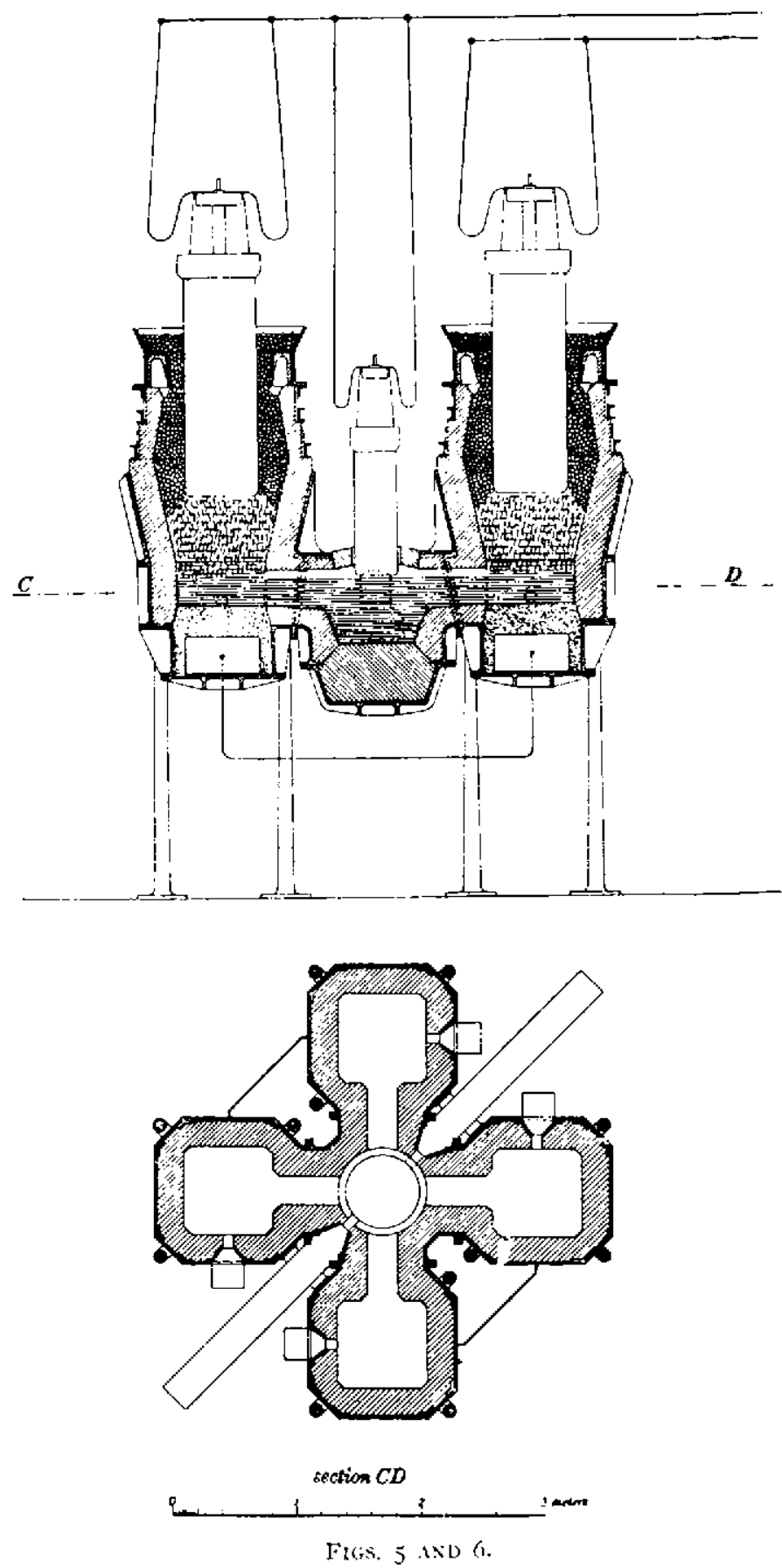
ment, at least two furnaces are necessary. In the event of the metal becoming chilled in the central well, it can be heated by a subsidiary electrode, provided for the purpose, to the required temperature for casting.

In the experiments at Livet this central well was not used, as, owing to the furnace having stood for 12 hours while the necessary connections were made for placing the recording wattmeter in the circuit, the crucible became chilled, and some metal set in the bottom; the subsidiary electrode not having been installed, it was decided to tap each furnace independently from a tap hole in each. The iron ore fluxes and coke were all broken to pass through a $I \frac{1}{2}$-inch ring, and mixed on the floor, and then taken by a lift to a staging over the furnace, from which they were discharged by a shoot on to the furnace platform. The charging was done by hand, the materials being thrown into the furnace with a shovel.

In starting the furnace a small quantity of the charge was thrown into the bottom of the two furnaces, and the electrode lowered upon it. The current was then switched on, and passed from the electrode through the material to the bottom carbon-block, and then by the outside copper conductor to the carbon-block in the second furnace, and through the charge then to the other electrode. The charge in each furnace is heated by the resistance offered, and as the metal is reduced it collects on the bottom of each furnace and in the connecting canal ; and when this connection is established, the curreut flows along this from one electrode to another, the current passing by the exterior conductors gradually diminishing as the reduced metal increases. The electrodes are then raised, and the furnace gradually charged until filled to the platform level. When fully charged comparatively little current passes through the external conductors; but on emptying the furnaces by tapping they act as a shunt, and enable the furnace to be worked continuously without very greatly varying the load on the alternator.

The furnaces at Livet are operated with an alternating current generated direct on the alternator at the voltage required. The alternator is a revolving field machine, has 16 poles and rotates at approximately 380 revolutions per minute, giving a periodicity of 50 cycles, and is directly connected to a horizontal shaft water-wheel controlled by a governor.

The regulation of the electric input is effected chiefly by the vertical adjustment of the electrodes by hand, but this is supplemented when required by adjusting the alternator field and the water-wheel governor. The load is entirely free from violent fluctuations and hand regulation requires a very small amount of attention, so that one man could readily regulate four or five furnaces. If desired, however, little difficuity should be experienced in designing an automatic regulator that would fulfil all requirements, and dispense with the services of this man.

The electric energy was measured by a Thompson recording wattmeter obtained from Paris, and this was calibrated after the experiments were completed under the same conditions as to volts, amperes, cycles, and temperature as those to which it had been subjected during the experiments. The current used in the first experiment was about 66 volts and II,000 amperes, but varied from 63 to 68 volts and 10,600 to 12,000 amperes. The run lasted 55 hours, and the following are results from wattmeter reading and powerfactor determination.

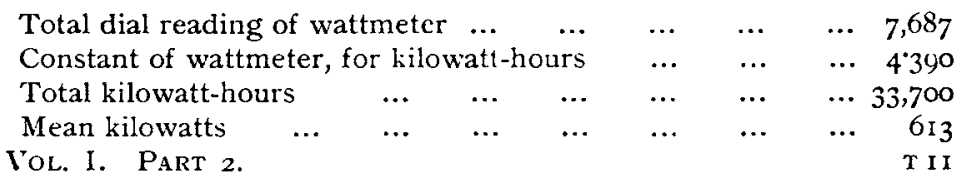


Mean power-factor from above determination ... $\quad \ldots \quad \ldots \quad \ldots \quad 0737$

$\begin{array}{llllllll}\text { Mean kilo-volt-amperes } & \ldots & \ldots & \ldots & \ldots & \ldots & \ldots & 832\end{array}$

$\begin{array}{lllllllll}\text { Mean E.H.P... } & \ldots & \ldots & \ldots & \ldots & \ldots & \ldots & \ldots & \ldots \\ \end{array}$

$\begin{array}{llllllll}\text { Total H.P.-hours } & \ldots & \ldots & \ldots & \ldots & \ldots & \ldots & \ldots 45,800\end{array}$

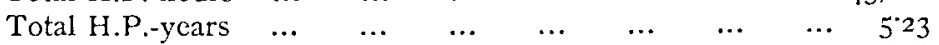

$\begin{array}{lllllllll}\text { Output of pig } & \ldots & \ldots & \ldots & \ldots & \ldots & \ldots & \ldots & 9,868\end{array}$

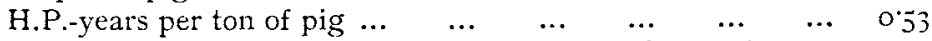

Cost of electric energy per ton of pig, at $4 \mathrm{Is} .8 \mathrm{~d}$. per horse$\begin{array}{llllllll}\text { power year } & \ldots & \ldots & \ldots & \ldots & \ldots & \ldots & 22 \text { s. Id. }\end{array}$

The points to which special attention was given during the experiments were-

I. Consumption of electric energy per ton of pig iron produced.

2. Consumption of coke as reducing agent per ton of pig iron produced.

3. The yield of metal.

4. Quality of the product.

The materials were all carefully weighed, but the furnace having to stop before all that was weighed out was used, what was left had to be estimated and deducted, which probably introduced a small error, both as regards yield and consumption of coke; but as the yield was controlled by weighing the slag and determining the percentage of iron it contained, and as the slag from practically ro tons of metal only contained $36 \mathrm{lbs}$. of iron, it is clear that all the ore charged was for practical purposes reduced.

At first, the iron made was very grey, and silicious, and contained 3.72 per cent. of silica, but on reducing the quantity of coke and altering the fluxes by removing some quartz from the charge, a very good grey iron was obtained. An average sample taken over three days' work gave the following analysis :-

\begin{tabular}{|c|c|c|c|c|c|c|c|}
\hline Total carbon & $\cdots$ & $\cdots$ & $\cdots$ & $\cdots$ & $\cdots$ & $\cdots$ & $\ldots \quad 4.200$ \\
\hline Combined & $\ldots$ & $\ldots$ & $\cdots$ & $\ldots$ & $\ldots$ & $\ldots$ & $0 \cdot 800$ \\
\hline Graphite ... & $\ldots$ & $\ldots$ & $\ldots$ & $\ldots$ & $\ldots$ & $\ldots$ & 3.420 \\
\hline Silicon $\quad \ldots$ & $\ldots$ & $\ldots$ & $\ldots$ & $\ldots$ & $\ldots$ & $\ldots$ & $r \cdot 9 I$ \\
\hline Sulphur ... & $\ldots$ & $\ldots$ & $\ldots$ & $\ldots$ & $\ldots$ & $\ldots$ & 0.007 \\
\hline Phosphorus & $\ldots$ & $\ldots$ & $\ldots$ & $\ldots$ & ... & $\cdots$ & $\ldots \quad 0^{\circ} 027$ \\
\hline Arsenic ... & $\ldots$ & $\ldots$ & me & $\ldots$ & ... & $\ldots$ & ... Trac \\
\hline
\end{tabular}

On further reducing the silica in the charge, the slag became somewhat infusible, and white iron of excellent quality low in silicon and sulphur was obtained.

As the furnace had been working very cold for a considerable time owing to I 2 hours' standing for altering connections, and this could not be remedied without increasing the electric energy, which would have interfered with the correct determination of energy required for reduction, Mr. Keller decided to stop the experiment and start with another furnace.

The first experiment had demonstrated that both grey and white iron suitable for foundry and steel-making purposes could be made, but it had not shown how far the composition of the pig iron could be varied at will; in fact, how far the variation in grade was under control. For Bessemer steel and acid Siemens steel manufacture, a grey pig iron with about 2'o of silicon is generally used, and for basic steel a white pig iron with I per cent. or less of silicon and low in sulphur is advisable, and it was important to know how far these different grades could be produced as required, and I therefore requested Mr. Keller to start with grey iron, pass to white, and then return to grey. This was done, and the results showed that there was no difficulty in 
making any variety of iron required, the operation being well under control by slightly varying the charge and the current passing into the furnace.

For the second experiment there was not sufficient time to have a complete analysis of the ore, $\&$ c., made before commencing, and Mr. Keller did not introduce sufficient lime, and this, with working the furnace at a very low temperature to economise the electric energy as much as possible, resulted in some cases in the production of iron extremely low in silicon and manganese, but high in sulphur. When, however, the temperature was maintained sufficiently high to reduce about 2 per cent. of manganese, a low sulphur pig iron was obtained.

So far as one was able to judge from these experiments, the reactions as regards reduction and combination of silicon, sulphur, phosphorus, and manganese with the iron are identical with those that take place in the blast furnace. The most essential condition for the production of low sulphur pig iron in the blast furnace is the maintenance of a fluid basic slag, which is facilitated by the presence of manganese in the furnace burden. The experiments showed that under the conditions in which 2 per cent. of manganese was reduced and passed into the pig iron, excellent low sulphur and low silicon pig iron was obtained. They did not, however, experimentally demonstrate that such a pig iron could be made in the absence of manganese; but in view of the fact that by increasing the current, and so raising the temperature, a far more basic slag can be maintained than in the blast furnace, there is every reason to believe that low sulphur pig iron would be produced under these conditions.

The following are the details of energy consumed :-

$$
\begin{aligned}
& \begin{array}{lllllll}
\text { Length of run, hours } \ldots & \ldots & \ldots & \ldots & \ldots & \ldots & 4^{8}
\end{array} \\
& \begin{array}{lllllll}
\text { Mean volts on furnace } & \ldots & \ldots & \ldots & \ldots & \ldots & 55^{\circ} 3
\end{array} \\
& \begin{array}{llllllll}
\text { Mean amperes } & \ldots & \ldots & \ldots & \ldots & \ldots & \ldots & 7,247
\end{array} \\
& \begin{array}{lllllll}
\text { Mean kilo-volt-amperes } & \ldots & \ldots & \ldots & \ldots & \ldots & 40 \mathrm{x}
\end{array} \\
& \begin{array}{llllll}
\text { Total kilo-volt-ampere hours } & \ldots & \ldots & \ldots & \ldots & \text { 19,240 }
\end{array}
\end{aligned}
$$

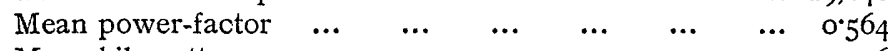

$$
\begin{aligned}
& \begin{array}{llllllll}
\text { Mean kilowatts } & \ldots & \ldots & \ldots & \ldots & \ldots & \ldots & 226
\end{array}
\end{aligned}
$$

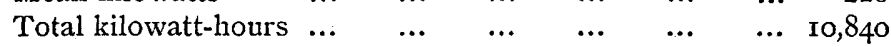

$$
\begin{aligned}
& \begin{array}{llllllllr}
\text { Mean H.P. } & \ldots & \ldots & \ldots & \ldots & \ldots & \ldots & \ldots & 10,840 \\
& & \ldots & \ldots & \ldots & \ldots & 308
\end{array}
\end{aligned}
$$

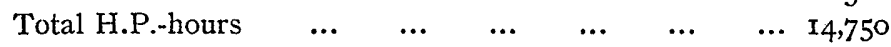

$$
\begin{aligned}
& \begin{array}{lllllllr}
\text { Total H.P.-years } & \ldots & \ldots & \ldots & \ldots & \ldots & \ldots & \text { I.6́9 }
\end{array} \\
& \begin{array}{lllllll}
\text { Output of pig iron, kgs. } & \ldots & \ldots & \ldots & \ldots & \ldots & 6,692
\end{array} \\
& \begin{array}{llllllll}
\text { H.P.-years per ton of pig } & \ldots & \ldots & \ldots & \ldots & \ldots & 0.25
\end{array}
\end{aligned}
$$

Cost of electric energy per ton of pig, at Io per H.P.-

$$
\begin{array}{llllllllll}
\text { year } & \ldots & \ldots & \ldots & \ldots & \ldots & \ldots & \ldots & \ldots & \$ 2.50
\end{array}
$$

It will be noticed that the total energy is less than one-half that used in the first experiment, which is due to the fact that nearly all the iron made was white, containing considerably less silicon and manganese; that a smaller quantity of fluxes was used, and a more siliceous and fusible slag formed; and that the whole operation was conducted at the lowest possible temperature. In my opinion it would not be possible to make pig iron regularly with such a small consumption of energy, but a mean of the two experiments is approximately what would be consumed in actual every-day practice. This estimate is confirmed by figures given me by $\mathrm{Mr}$. Keller as to the energy consumed in the manufacture of ferro-silicon alloys, and also by the result in a small furnace of Mons. Héroult's, in which about $18 \mathrm{cwt}$. of pig iron was made under very unfavourable conditions. 
The average amount of coke used as a reducing agent was 767 lbs. per ton of pig iron produced, and Mr. Keller estimates the cost of electrodes at about 3s. 6 d. per ton of iron.

There appears not the least doubt that pig iron, to meet all the requircments of the foundry and steel manufacture, can be produced in the electric furnace, but it is only under exceptional circumstances that the latter can compete with the blast furnace. Where electric energy is very cheap and fuel very dear, the commercial production of pig iron becomes possible. In some of the South American Republics, and similarly situated countries, provided ample water-power is available, electric smelting should certainly hold its own; but it is impossible to define the exact conditions under which it can be successfully carried on, and only when all the facts are known can an opinion be given as to its feasibility. Taking the results obtained at Livet, where coke costs about $\$ 7$ per ton and electric energy about \$1o per E.H.P.year, the cost of electric smelting is approximately the same as smelting in the blast furnace.

It must be remembered, however, that the experiments at Livet were conducted in furnaces usually used for the manufacture of alloys, and it is only reasonable to anticipate that with a plant especially designed, and with further experience, economies would be effected.

Alloys.-Although no experimental investigation was made respecting the electric smelting of alloys by the Canadian Commission, I had the opportunity at Livet of seeing these manufactured on a considerable scale. The furnaces used were identical with those employed in the pig iron experiments, and the only difference was in the alteration of the furnace mixture, and in the regulation of the electric current to obtain the necessary heat required for the particular operation. Ferro-chromes from about 45 per cent. to 60 per cent., and ferro-silicons from 25 per cent. to 80 per cent., were being made regularly, although 50 per cent. ferro-silicon was the alloy that they were making most largely at this particular time. In the manufacture of this alloy, a very high temperature is necessary to obtain a good tapping heat, and it is desirable to work with as little flux as possible, so that a very small quantity of slag is produced. The alloy is tapped into horizontal moulds holding about $2 \mathrm{cwt}$, and the little slag formed is raked off the surface of the alloy before it solidifies. In the manufacture of these alloys, oxide of iron is not used as the source of iron, but selected steel scrap. In the case of clurome alloys it is desirable to use rich chrome iron ore. The demand for these alloys is, so far as I am able to obtain information, undoubtedly increasing, many steel foundries using nothing below 25 per cent. to 30 per cent. ferro-silicons, and some nothing below 50 per cent. The increasing demand for chrome and tungsten alloys for the manufacture of the various special steels required for ordnance and other purposes is too well known to need comment.

Up to about $\mathrm{I} 2$ per cent. to I 5 per cent. ferro-silicons, and 40 per cent. ferro-chromes, the blast furnace is probably a more economical metallurgical appliance than the electric furnace, but for higher alloys the latter holds the field.

\section{THE ARC FURNACE.}

In this type of furnace the necessary heat is obtained by direct radiation from the arc and by reflection from the roof and sides of the furnace. As far back as 1879 the late Sir William Siemens designed a small crucible furnace capable of melting a few pounds of steel on this principle, and the Stassano furnace is the best-known furnace of this type used for the smelting of iron 
Rotating electric furnace.

Section A B.

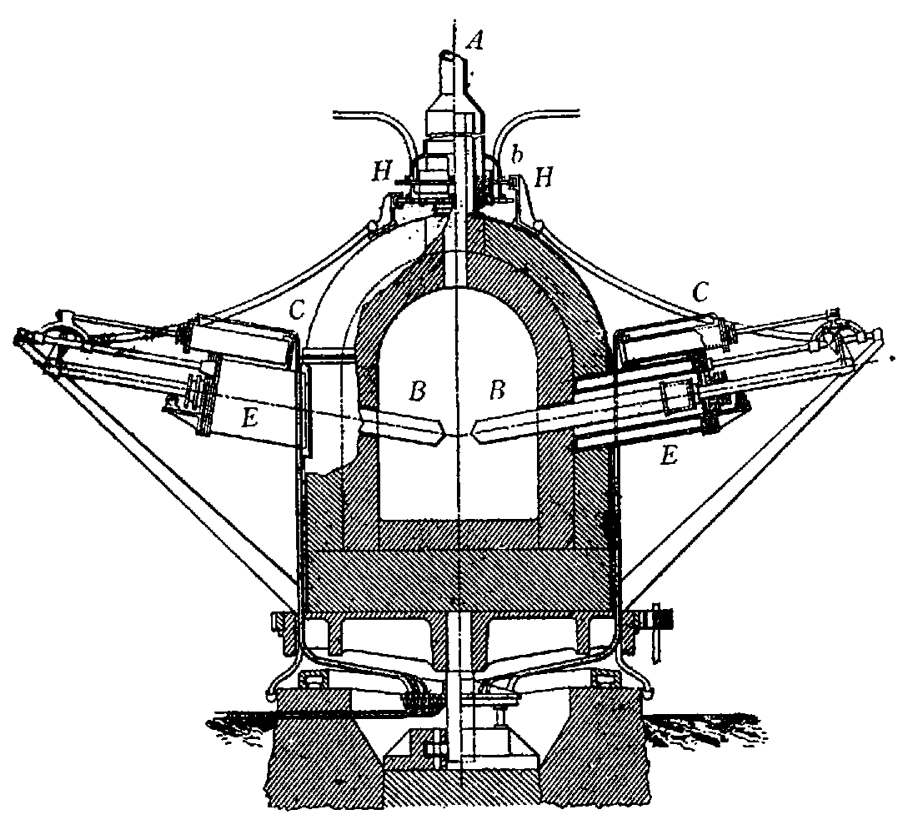

Section CD.

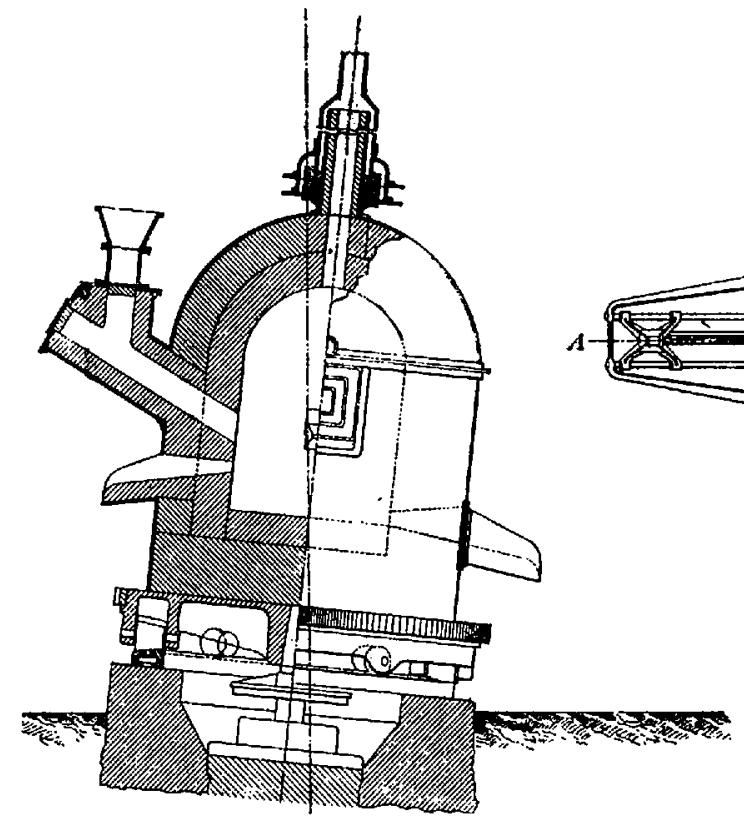

Top view.

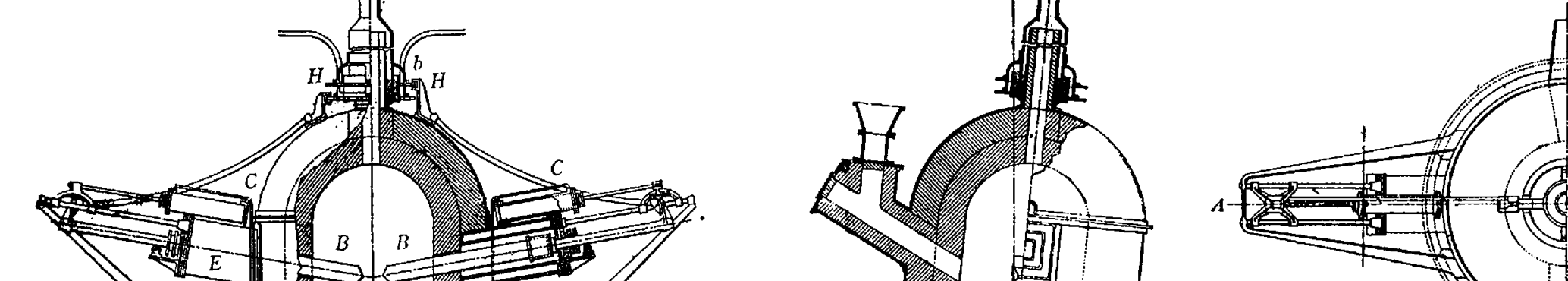

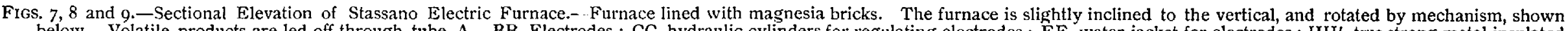

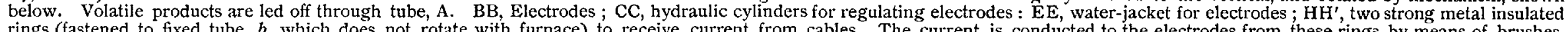

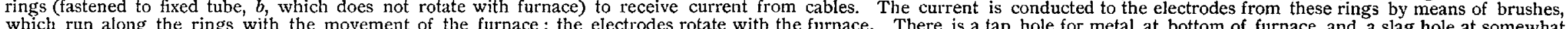
higher level. The charge is fed through a hopper and inclined shoot to deliver below the electrodes. 
and steel. It is shown in Figs. 7,8 , and 9, with a description attached. The furnace rotates round an axis inclined about $7^{\circ}$ to the vertical. There are three electrodes, which nearly meet in the centre of the furnace, their distance being regulated by a hydraulic ram. A three-phase alternating current is used and distributed between the three electrodes. In the latest type two pairs or four electrodes are used, and the following details of a $4^{\text {- to }}$ 5-ton $^{\text {-ton }}$ furnace were supplied by Captain Stassano to Dr. Haanel, the commissioner: sent over by the Canadian Government to report on electric smelting.

The furnace is capable of producing 4 or 5 tons of steel per day, a current of 4,900 amperes at 150 volts being distributed to four electrodes supplying two arcs with $2,45^{\circ}$ amperes for each arc. The electrodes are cylindrical in shape, about 6 inches in diameter, from 50 to 60 inches long, and weigh about $1_{32}$ lbs. The furnace is lined with magnesite blocks made specially to the shape of the furnace; even under unfavourable conditions these blocks will last forty days with slight repairs to the parts in contact with the slag.

The process differs from the Héroult and Keller processes, in so far that steel is produced direct from the ore in one furnace, instead of from pig iron or scrap. The ores used are the very purest hematites, and thesc, after most careful analysis, are ground very fine, and mixed with just sufficient fluxes to form a fusible slag, and with sufficient carbon to effect the reduction, and are then moulded into briquettes. The arc takes no part in the reduction, but simply supplies the heat, the reduction being effected entirely by the solid carbon. As there is no combustion of the carbon by oxygen, the reduction cannot be effected by carbonic oxide, but by the carbon; and hence it is necessary to have all the materials of the charge finely ground and briquetted, so that the oxides and carbon may be in very intimate contact. The rotation of the furnace also assists in maintaining this contact after the bath is molten. By very carefully adjusting the amount of carbon so that it is present in a just sufficient quantity to reduce the oxide, extremely soft pure iron practically free from carbon is obtained, which is stated to give exceptionally good results for dynamo purposes. By increasing the amount of carbon in the briqucttes, it is claimed that any product varying from dead soft steel to pig iron can be obtained. There is no doubt that the process has been worked ont most scientifically; and, under the special conditions as to very pure ores and cheap electric energy which exists in Northern Italy, may give good commercial results. In cases where comparatively impure ores have to be treated, the problem would, from a practical standpoint, be much more difficult, as not only would a greater amount of energy be absorbed in melting the slag produced, but the bulk of materials in the furnace would greatly restrict the output.

The furnace can equally well bc employed for scrap-melting and purifying, and at the Government Works at Turin is almost entirely charged either with scrap ог a mixture of scrap and pig iron. In a recent letter dated January 15, 1905, Captain Stassano sends me the following particulars:-

"The furnace at Turin has been working regularly since March last, producing normally the grade of steel required by the Government for the manufacture of artillery projectiles. The furnace is standing at present, in consequence of the transformer having been damaged, but a new one is being installed which will reduce the current from 3,000 to 80 volts; the furnace is expected to be ready to commence work again in March.

"The usual charge consists of $35^{\circ}$ to $400 \mathrm{kgs}$. of pig iron, 200 to $250 \mathrm{kgs}$. of

* Report of Canadian Comminssion on Electric Smelting, 1905, p. II. 
scrap, the necessary amount of ore being added to oxidise the impurities, and sufficient lime to form a basic slag to protect the lining of the furnace, and remove the phosphorus and sulphur in the materials employed. During the last year's working the following data have been obtained: Loss on weight of materials charged, $\mathrm{I}^{\prime} 5$ to $2^{\circ} \mathrm{Or}$ as a maximum; consumption of electrodes, $5 \mathrm{~kg}$. per ton of steel produced; mean consumption of current, $I^{*} \cdot 2 \mathrm{kw}$. per $\mathrm{kg}$. of steel produced, equal to $186 \mathrm{E}$.H.P.-year per ton of steel ; six men, including an electrical mechanic, melter, and four labourers are more than sufficient for one furnace."

Captain Stassano considers there is every reason to anticipate a reduction in the consumption of electric energy when the workmen have acquired greater experience, and when furnaces of larger size are installed, and there seems little doubt that this will be the case.

The average mechanical results are as follows :-

Max. stress, per sq. in.

$4 I^{\prime} 3$ to $45^{\circ} 7$ tons.
Elastic limit, per sq. in.

Ig to $20^{\prime} 3$ tons. Elong to elastic
limit.

I.5 to I.8 per cent.
Total elongation.

I6 to 19 per cent.

The length on which elongation is taken is not stated.

Unfortunately, when the Commission visited Turin, this furnace was not at work, so that the author did not see it in actual operation, but both as a steel meiter and for the direct smelting of the ore, it certainly offers considerable possibilities. The details of the design have been most carefully worked out as the result of numerous experiments, and its future development will be most carefully watched by all metallurgists interested in electrical smelting.

Various other processes both for the manufacture of steel and the direct smelting of ores have been proposed; but so far as the author is aware, although of considerable theoretical interest, none of them have been experimented with on a commercial scale.

Mons. Harmet, the well-known French metallurgist, has patented one or two processes of smelting which deserve consideration. In one form of furnace he proposes to melt oxides of iron and reduce them by solid carbon, and in another form he proceeds on ordinary blast-furnace lines, relying upon carbonic oxide as his chief reducing agent. The first form of furnace consists of a vertical shaft, in which the oxide of iron is melted by producer gas, the molten oxides being allowed to flow into a reducing chamber containing incandescent carbon, through which they percolate, and are reduced before being tapped off to the refining furnace for conversion into steel of the grade required. Theoretically, this furnace should give good results, but in the author's opinion there are many practical difficulties which would largely interfere with the success of the operation. This is a mere opinion, however, and he would be very sorry to condemn the process without further information, and especially without discussing the details fully with Mons. Harmet. In the melting and reducing chamber electrodes are provided to supplement the heat developed by the combustion of the gas when necessary, and the finishing or regulating chamber is practically an open-hearth furnace electrically heated by electrodes passing through the roof, as in the Héroult and Keller furnaces. One disadvantage of any process of this kind is that the steel furnace is not independent of the reducing furnace, or what corresponds to the blast furnace in an ordinary iron and steel works, and consequently irregularity in the working of this portion of the plant interferes with and retards the steel manufacture. There appears no reason why, with slight modifications, the steel furnace could not be separated, a mixer being used to receive the metal from the reducing furnace, from which it could be trans- 
ferred to the steel furnaces as required. The advantages claimed are that the process enables a much cheaper fuel to be employed than is used in the blast furnace, and that the ore being in contact with the fuel during a short period only, does not take up impurities from the fuel to the same extent.

The other process suggested by Mons. Harmet depends upon the reduction of solid oxides of iron by carburised gases.

The materials, previously calcined and preheated to a temperature of $500^{\circ}$ by waste gases, are charged with preheated coke into the top of a shaft furnace similar to an ordinary blast furnace, electrodes being arranged in the crucible of the furnace to furnish the necessary heat units for the fusion of the reduced metal; a portion of the gases taken from the furnace top are forced into the bottom of the furnace by a blowing engine, and these serve the double purpose of carrying some of the heat units generated electrically and distributing them through the charge, and of acting as reducing agents. The composition of the gases leaving the furnace top will vary with the system of working, and provided a rapid circulation of the gases is maintained, so that the temperature at the top is about $500^{\circ} \mathrm{C}$., they will consist largely of carbon monoxide with little carbonic dioxide ; if the circulation of the gases is slower, the temperature at the top of the furnace will be lower, and the proportion of carbon dioxide will be much greater, as the temperature will not be sufficiently high for the carbon dioxide to combine with carbon to form carbon monoxide. Whichever method of working is adopted, the carbon dioxide injected with the furnace gases at the bottom coming into contact with the incandescent carbon in the charge, is converted into carbon monoxide, which acts as a reducing agent to the oxide of iron, being again converted into carbon dioxide and again reduced to carbon monoxide so long as the temperature is sufficiently high for the reactions to takc place. These reactions are identical with those taking place in the blast furnace above the fusion zone, except that we should anticipate that the reducing action of the gases would be more energetic, as they are not diluted by any inert nitrogen. Mons. Harmet claims that this furnace forms the most perfect gas-producer invented, as, working under conditions of rapid circulation, he is able to produce a combustible gas consisting almost entirely of carbon monoxide, and that the reducing conditions are far superior to the blast furnace. From a series of calculations as to the heat units required for the production of one ton of steel, including the reduction and final finishing in the steel furnace, on the basis of coke at 25 francs. per ton, and electric energy at the price usually allowed in the French Alps ( $0^{\circ}$ or fr. per $x$, ooo electric calories), Mons. Harmet estimates there is a balance in favour of electric smelting of from 21 to 16 francs per ton of steel. This process is extremely ingenious, and the details both as to plant and method of working have been most car efully thought out ; it is a very fascinating process, theoretically perfect, and is one which one would very much like to see tried under favourable conditions as to cost of electric energy. The plant as designed by Mons. Harmet would probably have to be considcrably modified, as one can foresee considerable practical difficulties in carrying out all the operations in the manner suggested; but this could probably be done without interfering with the fundamental principle of reducing the ore by practically pure carbon monoxide, which is an entirely new departure so far as the commercial production of iron is concerned.

The Gin Furnace.

There is one other electric furnace which calls for a short description, as it is different in principle and design to those already described. The Gin furnace was designed to avoid the disadvantages attending the use of carbon 


\section{${ }^{8} 5^{8}$ ELEC'TRIC SMELTING IN CONNECTION}

electrodes, and it is also claimed by its author to have considerable advantages over the induction furnace.

The furnace hearth consists of a trough or channel of considerable length and small cross-section; this channel is filled with molten pig iron, and terminal water-cooled blocks are provided for connecting to the electric circuit. For convenience, the channel which holds the metal is doubled upon itself several times, so that in plan it has the form of a huge filament of an incandescent lamp. By varying the current passing into the fused metal any required temperature can be obtained. It is stated that by having the terminal blocks of very large section in comparison with the section of the channel carrying the molten metal, and by internal water-cooling, they are prevented from attaining a very ligh temperature. The furnace is basic-lined, and can be used as a crucible or melting furnace for the production of stecl, by melting selected pure materials to give the composition of steel required, or it can be used with pig and scrap, additions of ore, lime, \&c., being made in the usual way to effect the oxidation and removal of impurities. The author is not aware if this furnace has actually yet been tried on a commercial scale, and cannot express any opinion as to the advantages it may offer from an electrical standpoint, but he thinks that any practical metallurgists present who have had experience with Siemens furnaces, will agree with him that from a metallurgical point of view this is not a furnace likely to give satisfactory results. The difficulty of charging the pig iron, scrap, ore, \&c., into such a furnace during the working of the charge, and the maintaining of the hearth or channel in fair repair, seems to rule out a furnace of this design for the manufacture of steel on anything like a commercial scale. The maintenance of the terminal blocks, notwithstanding water-cooling, would also probably be attended with considerable difficulty.

\section{GENERAL CONCLUSIONS.}

The following, given in the Canadian Report, were the general conclusions arrived at by the author as the result of his investigations, and of the information he was able to obtain from various sources. They represent what are, in his opinion, the possibilities of electric smelting in the present state of the art; but, no doubt, future developments and improvements will necessitate that these conclusions be greatly modified in the near future.

I. Steel, equal in all respects to the best Sheffield crucible steel, can be produced, either by the Kjellin or Héroult or Keller processes, at a cost considerably less than the cost of producing a high-class crucible steel.

2. At present, structural steel to compete with Siemens or Bessemer steel, cannot be economically produced in the electric furnaces, and such furnaces can be used commercially for the production of only very high-class steel for special purposes.

3. Speaking generally, the reactions in the electric smelting furnace as regards the reduction and combination of iron with silicon, sulphur, phosphorus, and manganese, are similar to those taking place in the blast furnace. By altering the burden and regulating the temperature by varying the clectric current, any grade of iron, grey or white, can be obtained, and the change from one grade to another is effected more rapidly than in the blast furnace.

4. Grey pig iron, suitable in all respects for acid steel manufacture, either by Bessemer or Siemens processes, can be produced in the electric furnace.

5. Grey pig iron, suitable for foundry purposes, can be readily produced.

6. Pig iron low in silicon and sulphur, suitable either for the basic Bessemer or the basic Siemens process, can be produced, provided that the ore 
mixture contains oxide of manganese, and that a basic slag is maintained by suitable additions of lime.

7. It has not been experimentally demonstrated, but from general considerations there is every reason to believe, that pig iron low in silicon and sulphur can be produced even in the absence of manganese oxide in the iron mixture, provided a fluid and basic slag be maintained.

8. Pig iron can be produced on a commercial scale at a price to compete with the blast furnace, only when electric energy is very cheap and fuel very dear. On the basis taken in this report, with electric energy at \$ Io (4Is. 8d.) per E.H.P.-year, and coke at $\$ 7$ (29s. 2d.) per ton, the cost of production is approximately the same as the cost of producing pig iron in a modern blast furnace.

9. Under ordinary conditions, where blast furnaces are an established industry, electric smelting cannot compete; but in special cases, where ample water-power is available, and blast furnace coke is not readily obtainable, electric smelting may be commercially successful.

It is impossible to define the exact conditions under which electric smelting can be successfully carried on. Each case must be considered independently after a most careful investigation into local conditions, and it is only when these are fully known that a definite opinion as to the commercial possibilities of any project can be given.

The illustrations in this paper have been reproduced from the Canadian Report by permission of Dr. Haanel.

In all cases the H.P.-year is taken for 365 days of 24 hours. 